\title{
THE GENUS EUPELMUS DALMAN, 1820 (HYMENOPTERA, CHALCIDOIDEA, EUPELMIDAE) IN PENINSULAR SPAIN AND THE CANARY ISLANDS, WITH TAXONOMIC NOTES AND DESCRIPTIONS OF NEW SPECIES
}

\author{
R. R. Askew (*) and J. L. Nieves-Aldrey (**)
}

\begin{abstract}
The occurrence of twenty-six species of Eupelmus Dalman in peninsular Spain and the Canary Islands is reported. Eleven species are newly recorded for Spain. Taxonomic, distributional and biological data are given. Two new species and one new subspecies are described. Eupelmus matranus Erdös is removed from synonymy under E. splendens Giraud and accorded specific rank; E. valentinus Bolívar is newly synonymized under E. testaceiventris (Motschulsky) and E. capillaris Bolívar under E. fuscipennis Förster. A key to females is provided.

Key words: Hymenoptera, Chalcidoidea, Eupelmidae, Eupelmus, Macroneura, Spain, Canary Islands, new species, key.
\end{abstract}

\section{RESUMEN}

El género Eupelmus Dalman, 1820 (Hymenoptera, Chalcidoidea, Eupelmidae) en España peninsular e islas Canarias, con notas taxonómicas y descripción de especies nuevas

Se citan 26 especies de Eupelmus Dalman de España peninsular e Islas Canarias, 11 de las cuales se citan por primera vez en España. Se describen dos especies y una subespecie nuevas para la ciencia y se aportan nuevos datos taxonómicos, de biología y de distribución de todas las especies listadas. Eupelmus matranus Erdös se rehabilita de sinonimia con E. splendens Giraud, otorgándole rango específico válido. Eupelmus valentinus se sinonimiza de nuevo con E. testaceiventris (Motschulsky) y E. capillaris Bolívar con E. fuscipennis Förster. Se incluye una clave de identificación de las especies basada en las hembras.

Palabras clave: Hymenoptera, Chalcidoidea, Eupelmidae, Eupelmus, Macroneura, España, Islas Canarias, especies nuevas, clave de identificación.

\section{Introduction}

Eupelmus Dalman, 1820 is here considered, following Ruschka (1921) and Gibson (1995), to include species sometimes placed in the genus Macroneura Walker, 1837 (= Eupelmella Masi,
1919). Macroneura and Eupelmus are treated as subgenera. Eupelmus is well-represented in the Iberian Peninsula and new species have been described from Spain, five by Bolívar (1933) and one by Gijswijt (1993). Ceballos (1956) catalogues only seven species, but the total number of recognized Spanish spe-

* RRA: 5, Beeston Hall Mews, Beeston, Tarporley, Cheshire CW6 9TZ, England

** JLNA: Museo Nacional de Ciencias Naturales, Departamento de Biodiversidad y Biologia Evolutiva, José Gutierrez Abascal 2, 28006 Madrid, España. E-mail: aldrey@mncn.csic.es 
cies is now increased to twenty-six. Some of this increase stems from studies of material housed in the Museo Nacional de Ciencias Naturales (Madrid), much of it collected by García Mercet and Bolívar y Pieltain in the first half of the twentieth century. Substantial contributions to our knowledge of Iberian Eupelmus have been made more recently by Nieves-Aldrey (1982) rearing from galls of Cynipidae (Hymenoptera) on Quercus in Salamanca and by Pujade (1989) rearing from a diversity of galls in Catalunya, by Gijswijt (1993) collecting on Juniperus thurifera L. in Soria, and by Javier Blasco-Zumeta collecting in Los Monegros (Zaragoza). More general collecting in mainland Spain by Z. Boucek, the authors and others, and in the Canary Islands by M. Báez, M. Koponen and others, has contributed additional information.

Two new species and one new subspecies are described here. E. matranus Erdös is recognized as a species distinct from E. splendens Giraud. A key is provided to the species found in Spain and the Canary Islands.

In the following alphabetically arranged list of Spanish Eupelmus, abbreviations are as follows: $\mathrm{CBP}=\mathrm{C}$. Bolívar y Pieltain, JBZ $=\mathrm{J}$. BlascoZumeta, JNA $=$ J. Nieves Aldrey, JPV $=$ J. Pujade i Villar, $\mathrm{MNCN}=$ Museo Nacional de Ciencias Naturales (Madrid), $\mathrm{RGM}=\mathrm{R}$. García Mercet, $\mathrm{RRA}=\mathrm{R} . \mathrm{R}$. Askew.

\section{Eupelmus (Eupelmus)}

\section{E. aloysii Russo, 1938: 229-231}

New record for Iberian Peninsula (Andorra): Santa Coloma, 1993, JPV, 1 우.

A second female specimen is in $\mathrm{MNCN}$; it is without locality but evidently of Italian origin, labelled with a neatly written list (in Italian) of morphological characters, 'agosto 1935-xiii - da Fleotribo-olivo', 'Colección $\mathrm{G}^{\mathrm{A}}$. Mercet' and '7'.

Russo (1938) described E. aloysii from material reared in Italy from a branch of olive (Olea europea L.) infested with larvae of Phloeotribus scarabaeiodes (Bernard) (Coleoptera, Scolytidae).

\section{E. annulatus Nees, 1834: 175-176}

Recorded by Nieves-Aldrey (1982) from Salamanca, and Pujade (1989) from Catalunya, as a parasitoid in a range of galls of Cynipidae (Hymenoptera) on Quercus.
Specimens in MNCN are from Almería, Madrid and Segovia, collected by CBP, RGM and Lauffer. 1 ㅇ Cercedilla (Madrid), viii.1916, leg. Bolívar has relatively well-developed wing marks. More recent records are from Zaragoza (1992, JBZ) and Lérida (1996, RRA).

\section{E. atropurpureus Dalman, 1820: 381}

Ruschka (1921) mentions having seen specimens of E. atropurpureus from peninsular Spain.

Additional material: Madrid, 1922, RGM and 1923, CBP (MNCN); Santander, 1922, RGM (MNCN); Almería, no date or collector, ex Mercet collection (MNCN); Salamanca, no date or collector, ex Mercet collection (MNCN); Zaragoza, 1980, P. J. Chandler and 1991, JBZ; Huesca, 1997, JBZ and undated, CBP (MNCN); Zamora, Toro, 1986, ex gall Isocolus lichtensteini (Mayr) on Centaurea aspera L., JNA; La Coruña, Puerto del Son, 1994, JNA.

\section{E. cerris Förster, 1860: 128}

Recorded from peninsular Spain by NievesAldrey (1982) as a parasitoid in galls of Synophrus politus Hartig (Hym., Cynipidae) on Quercus suber L. in Salamanca. Also found in Madrid (El Pardo), two females emerging 10.vi.1999 from galls of the same host on $Q$. suber, JNA.

\section{E. clavicornis Askew sp. n. (fig. 7)}

TYPe MATERIAL: Holotype + . Zaragoza, Pina de Ebro, Retuerta de Pina. Reared from a gall of Etsuhoa thuriferae Skuhravá, 1995 (Dipt., Cecidomyiidae) on Juniperus thurifera, collected 1.viii.1991, J. Blasco-Zumeta. Deposited in MNCN.

Paratypes. $1 \stackrel{\circ}{\circ}$, same data as holotype; $1 \stackrel{+}{\circ}$, same data as holotype except gall collected 28.viii.1991.

FEMALE. Head dark green, shining, with coppery reflections from lower face; antenna with scape and most of pedicel black, weakly metallic; anellus and pedicel at extreme apex pale yellowish; remaining flagellum unicolorous brown. Mesoscutum shining green, coppery anteriorly; scutellum, axillae and sides and venter of thorax mainly coppery. Wings hyaline; venation pale yellow; microtrichiae pale. Legs with coxae concolorous with thorax; femora pale yellow, darkened over about proximal threequarters (the holotype has darkening only on dorsal surface); tibiae pale yellow with a variably develo- 

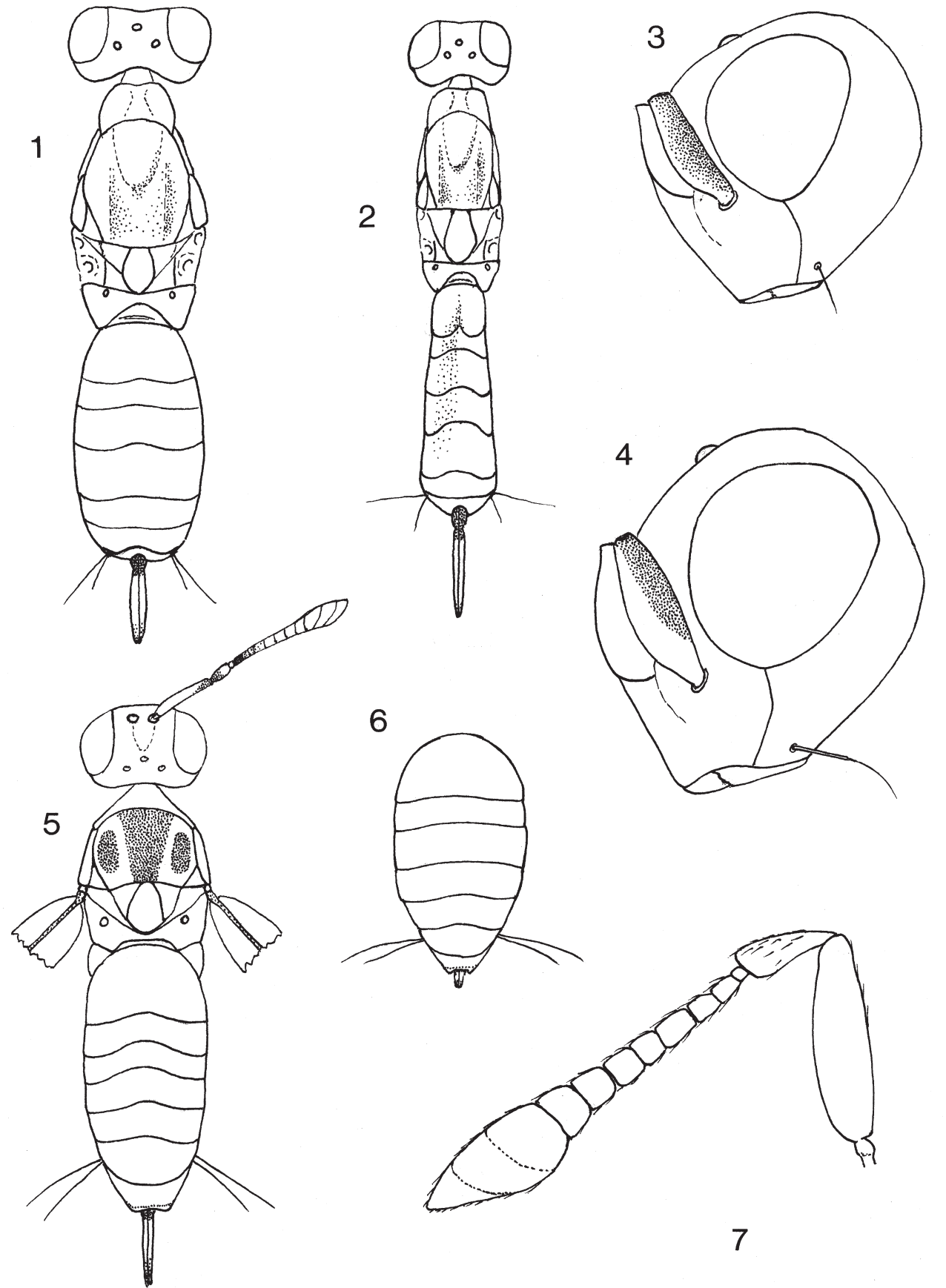

Figs. 1-7.- Eupelmus species. 1) E. matranus Erdös, body of 우 leg. Mercet; 2) E. splendens Giraud, 우 body (reared ex Pediaspis gall, France); 3) E. splendens, $\sigma^{7}$ head; 4) E. matranus, $\sigma^{7}$ head showing long genal seta; 5) E. juniperinus Bolívar, body of $\$$ paratype (dark areas of mesoscutum and antenna are stippled); 6) E. juniperinus thuriferae subsp. nov., 9 gaster; 7) E. clavicornis sp. nov., ㅇ antenna.

Figs. 1-7.- Especies de Eupelmus. 1) Cuerpo de la $\odot$ de E. matranus Erdös (leg. Mercet); 2) cuerpo de la $ᄋ$ de E. splendens Giraud (obtenida de agallas de Pediaspis en Francia); 3) cabeza del $\sigma^{7}$ de E. splendens; 4) cabeza del $\sigma^{7}$ de E. matranus en la que se ve la larga seta genal; 5) cuerpo del paratipo $ᄋ$ de E. juniperinus Bolívar (las áreas oscuras de antena y mesoescudo son pun-

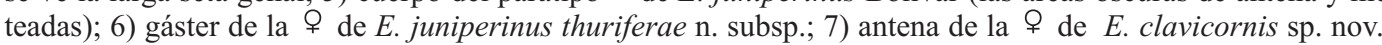


ped subbasal brown ring; tarsi with at least basal three segments pale yellow. Gaster with first tergite green, otherwise mainly coppery; ovipositor sheaths mostly pale yellow but with basal two-fifths brown and some indefinite darkening at apex, the extreme apical margin of the sheath black. Length 1.3 (holotype) - $1.6 \mathrm{~mm}$.

Head in dorsal view twice as broad as long; POL 2.2 OOL, posterior ocellus separated from orbit by about 1.2 times its diameter; vertex almost smooth. Head in front view about 1.1 times as broad as high; eyes separated by half head breadth; sculpture of face weak, frons almost smooth, weak striate-reticulate sculpture between eye and mouth; scrobal area not strongly excavated and no ridge between scrobe and eye. Antenna (fig. 7) with pedicel plus flagellum only very slightly longer than breadth of head; scape not expanded, not reaching level of anterior ocellus; pedicel 0.26 times length of flagellum, about as long as anellus plus funicle segments 1-3; anellus subquadrate; funicle broadening distally, basal four segments narrower than pedicel, F1-3 rather longer than broad, F6 subquadrate and about as broad as pedicel, F7 transverse; clava large, comprising almost 0.4 times length of flagellum, not quite twice as long as broad, more than twice as broad as pedicel.

Thorax dorsally and laterally mainly smooth and shining with sculpture indicated weakly only on scutellum, axilla and front of mesopleuron. Scutellum longer than broad. Mesotibia without apical pegs; mesobasitarsus with small, pale pegs; metacoxa with dorsal surface bare except for long apical setae.

Forewing completely pilose except for elongateoval speculum, but hairs small, pale and difficult to see; ratios of lengths costal cell: marginal vein: stigmal vein: postmarginal vein as 22:12:11:6.

Gaster excluding ovipositor sheaths a little longer than mesosoma (13:12); ovipositor sheaths half length of rest of gaster and 0.7 times length of hind tibia.

MALE. Unknown.

Etymology. Clava (Latin), club; cornus (Latin), antenna.

Biology. Three species of Eupelmus have been reared from the Oligotrophus-like galls of Etsuhoa thuriferae collected in the relict juniper woodland of the Retuerta de Pina. The dominant species was E. pallicornis Gijswijt, with E. urozonus Dalman and E. clavicornis scarce. Gijswijt (1993) found $E$. pallicornis plentiful as a parasitoid of a cecidom- yiid, presumably E. thuriferae, galling $J$. thurifera near Soria, with small numbers of $E$. urozonus, but no indication of the presence of a third species of Eupelmus in the galls.

COMMENTS. Eupelmus clavicornis is a small species which may be recognized by its almost smooth thoracic dorsum including the scutellum, together with its pale and inconspicuous mesobasitarsal pegs, metallic prepectus and tegulae, partially darkened femora and pale-banded ovipositor. The apparently bare proximal half of the dorsal surface of the metacoxa distinguishes E. clavicornis from almost all other Palaearctic species of Eupelmus ( $E$. hungaricus Erdös is the only other species in which this character has been noted).

\section{E. fulvipes Förster, 1860: 127}

New record for peninsular Spain: Segovia, San

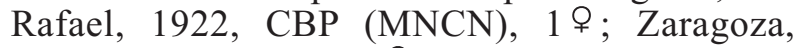
Nuevalos, 1994, JNA, 1 ㅇ.

This species is allied to E. urozonus but has almost entirely pale femora and tibiae.

Eupelmus sp. indet.

Jaén, 1974, RRA, 1 오.

Like E. fulvipes, this species has pale femora and tibiae, but it differs in having pale mesobasitarsal pegs.

E. fuscipennis Förster, 1860: 116

Eupelmus capillaris Bolívar, 1933: 195-197 syn. n.

Zaragoza, Pina de Ebro, 1991, JBZ, 5 우 우 .

No material referable to E. capillaris Bolívar could be found in MNCN and its synonymy under E. fuscipennis is based solely upon Bolívar's original description. This mentions, in particular, pale mesobasitarsal pegs, ovipositor all black and twice as long as hind tibia, and the scape 2.3 times as long as broad, all characters of $E$. fuscipennis. However, at variance with E. fuscipennis, is Bolívar's statement that the wings of E. capillaris are clear.

\section{[E. hartigi Förster, 1841: 33]}

Eupelmus hartigi is known from localities in central and southern Europe (Boucek, 1977) north 
to Britain (Graham, 1969) but it has not yet been found inhabiting Spain.

A specimen in the Museo Nacional de Ciencias Naturales in Madrid is believed to be of Italian provenance, probably sent to Mercet together with the specimen of $E$. aloysii mentioned above. Data are: 1 ㅇ ex Mercet collection (MNCN) labelled 'Portici do Fleotribo. Eupelmus ... [3 illegible words] ... 1935 ' and ' 2 '. It agrees reasonably well with the redescription and figure of $E$. hartigi in Ruschka (1921), based upon two Förster specimens.

\section{E. hungaricus Erdös, 1959: 327-330}

New record for peninsular Spain: Zaragoza, Pina de Ebro, Retuerta de Pina, Malaise trap, 20.vi.1991, JBZ, 1 ㅇ.

The type of E. hungaricus could not be found when looked for in the Hungarian National Museum (Budapest) in 1996, but the Spanish specimen agrees closely with the original description and figure.

\section{E. juniperinus Bolívar, 1933: 204, 205 (fig. 5)}

Described from peninsular Spain (Madrid, Zarzalejo near El Escorial) from specimens collected on Juniperus oxycedrus L. The holotype is believed to be lost, but two females located in MNCN are clearly from the type series and have been labelled as paratypes. Each bears a similar handwritten label 'Zarzalejo G. Mercet' and a printed label 'Colección $\mathrm{G}^{\mathrm{A}}$. Mercet'; neither date nor association with $J$. oxycedrus are stated.

A Eupelmus similar to nominotypical E. juniperinus was found on Juniperus thurifera at Soria by Gijswijt (1993) and at Zaragoza by JBZ. Specimens associated with $J$. thurifera, however, have a much shorter ovipositor than those found on J. oxycedrus, and it is thought appropriate to recognize them as a new subspecies:

Eupelmus juniperinus thuriferae Askew subsp. $\mathbf{n}$. (fig. 6)

Material: Holotype $ᄋ$. Zaragoza, Pina de Ebro, Retuerta de Pina, swept from Juniperus thurifera, 22.v.1992, J. BlascoZumeta. Deposited in MNCN.

Paratypes. Same locality as holotype, $1 \stackrel{\circ}{ }$, Moericke trap, 11.vii.1990, JBZ; 1 웅, colour water trap, 2.viii.1990, JBZ; 1 을, Malaise trap, 23.ix.1991, JBZ; 2 우, reared from male cones of $J$. thurifera collected 22.ii.1992 and 10.iv.1992, JBZ; 1 우, swept from J. thurifera, 8.viii.1992, JBZ. Soria, El Burgo de Osma, 2 ㅇ $\odot$ on J. thurifera, 15 and 19.vi.1994, M. J. Gijswijt. Additional material. Males trapped by JBZ in the Retuerta de Pina, probably conspecific with the above females, were collected as follows: $10^{7}$, Moericke trap, 28.v.1990; $40^{7} \sigma^{7}$, Malaise trap, 18.ix.1990; $10^{\pi}$, Malaise trap, 10.ix.1991.

Female. Form and colour as in E. juniperinus Bolívar except for ovipositor sheaths (fig. 6) which are very short, only 0.34 times length of hind tibia and 0.13 times length of rest of gaster ( 0.63 and 0.33 times respectively in nominotypical form (fig. 5).

\section{Etimology. From Juniperus thurifera.}

\section{E. linearis Förster, 1860: 119}

New record for peninsular Spain: Madrid, Galapagar, without date, RGM (MNCN), 1 .

\section{E. longicorpus Girault, 1915: 6}

Boucek (1988: 561) mentions having seen material of this primarily Australian species from Spain (also India and Zimbabwe). We are unable to provide further information on its Spanish status, and the species is not included in the key below.

\section{E. matranus Erdös, 1947: 68-70 stat. rev.} (figs. 1, 4)

Eupelmus splendens Bolívar, 1933: 201-203 nec Giraud, 1871

Bolívar's type of his E. splendens, collected at Loeches (Madrid) on 5.v.1924, has not been traced, but a specimen in the Mercet collection (MNCN) agrees with the description: Gerona, Palamós, 5.ix.1927 [written as 5-9-927 in Mercet's style], 1 우.

Boucek (1977) placed both E. splendens Bolívar (invalid homonym) and E. matranus Erdös in synonymy with Eupelmus splendens Giraud, 1871, but $E$. splendens Giraud, a parasitoid in galls of Pediaspis (Hym., Cynipidae), is distinct from E. matranus (type in Budapest seen). This confirms Pujade's (1989) doubts about the correctness of the synonymy of the Giraud and Bolívar species, based upon the absence of Pediaspis from the type locality of $E$. splendens Bolívar.

Females of E. matranus (fig. 1) differ from those of E. splendens Giraud (fig. 2) in being larger and relatively broader with longer ovipositors, as indicated in the key to species. Additionally, the antenna of E. matranus is relatively longer (pedicel 
plus flagellum at least 1.1 times breadth of head; in E. splendens their combined length scarcely greater than breadth of head) and less strongly clavate than that of E. splendens with the seventh funicle segment less than twice as broad as F1 (fully twice as broad in E. splendens) and the clava as long as the pedicel plus first two flagellar segments (only as long as pedicel plus anellus in E. splendens).

A male $E$. matranus, collected with a female at St Georges Blancaneix near Bergerac, Dordogne, France (27.v.1981, RRA) differs from reared males of $E$. splendens in having a much longer genal seta. The seta is as long as the genal sulcus (fig. 4) whereas in E. splendens the genal seta is only about half the length of the sulcus (fig. 3). Also, the whole of the anterior face of the scape is yellow in E. matranus whereas in male E. splendens the scape is yellow only at the extreme base and sometimes along its anterior edge.

\section{E. microzonus Förster, 1860: 125}

New record for peninsular Spain where it appears to be widespread. The following material is in MNCN: Madrid, El Escorial, no date, Lauffer in Mercet collection, El Pardo, 1922 and 1923, RGM, Vaciamadrid, no date, RGM, Collado-Mediano, 1927, CBP, Torrelodones, 1906, Cabrera; Segovia, San Rafael, 1917, CBP; Almería, no date, in Mercet collection; Zaragoza, Ambel, no date, Dusmet. Further specimens have been taken in Jaén, 1974, RRA; Toledo, Dosbarrios, 1974, RRA; Granada, Puerto del Moro, 1974, RRA; Guadalajara, La Alcarria, 1996, RRA; Zaragoza, Pina de Ebro, 1991, JBZ.

Material reared from galls of the following has also been examined:

Myopites sp. (Diptera, Tephritidae) on Inula crithmoides L., Portugal, Algarve, 1999, M. Boness Aylax minor Hartig (Hym., Cynipidae) on Papaver sp., Madrid, 1994, F. Ronquist; on P. rhoeas L., Madrid, Arganda, 1995, JNA; on P. rhoeas, Portugal, Serra de Arrabida, 1985, JNA.

Barbotinia oraniensis (Barbotin) (Hym., Cynipidae) on Papaver sp., Madrid, Arganda, 1986, JNA.

Isocolus lichtensteini (Mayr) (Hym., Cynipidae) on Centaurea aspera L., Madrid, Camporeal, 1985, JNA and Zamora, Toro, 1986, JNA.

Phanacis centaureae Förster (Hym., Cynipidae) on Centaurea sp., Madrid, 1994, F. Ronquist and Segovia, Tabladillo, 1985, JNA; on C. scabiosa L., Guadalajara, Pozo de Guadalajara, 1984, JNA and Soria, Aldehuela de Calatañazor, 1989, JNA.

\section{E. moroderi Bolívar, 1933: 197-199}

The holotype from Bétera (Valencia), collected by Moroder, is in MNCN. No other specimen from mainland Spain has been seen, but E. moroderi is a common species on the Canary Islands (Gijswijt, 1990). Specimens have been seen from Gran Canaria, La Gomera, La Palma and Tenerife collected by M. Báez (1980-1999), P. J. Chandler (1976), M. Koponen (1992-9), G. Ortega (1980) and RRA (1999). It seems to be associated with a host, almost certainly a cecidomyiid (Dipt.), on the endemic Canarian grass Hyparrhenia hirta (L.).

\section{E. pallicornis Gijswijt, 1993: 10-12}

Described from material reared in abundance from cecidomyiid (Dipt.) galls, subsequently identified as those of Etsuhoa thuriferae Skuhravá, on Juniperus thurifera at Soria in 1987, M. J. Gijswijt, and reared from the same host at Zaragoza, Pina de Ebro, 1991-2, JBZ.

\section{E. rostratus Ruschka, 1921: 291-293}

New record for peninsular Spain: Zaragoza, Pina de Ebro, Retuerta de Pina, JBZ: 1 ㅇ, Malaise trap, 24.v.1991; 2 \% ᄋ, Wilkening trap in Juniperus thurifera, 14.iv and 13.v.1994.

Reared from cynipid galls on Quercus in central Europe.

E. splendens Giraud, 1871: 416 (figs. 2, 3)

Reported by Pujade (1989) as a parasitoid in galls of Pediaspis aceris (Gmelin) (Hym., Cynipidae) on Acer monspessulanum L. in Catalunya (Montserrat). Distinctions between this species and $E$. splendens Bolívar are given under $E$. matranus.

E. stenozonus Askew sp. n. (figs. 8, 9)

Material: Holotype $\odot$ Spain, Canary Islands, La Gomera, above Santiago, 28.iii.1999, R. R. Askew. Deposited in MNCN.

Paratypes. Spain, Canary Islands, Tenerife, Icor, 21.iii.1999, 2 우 우; Arico Viejo, La Sabinita, 20.iii.1999, 1 우; Chimiche, 20.iii.1999, $10^{x} 2$ 우 $ᄋ$. La Gomera, Barranco de Santiago, 26.iii.1999, 10" . All leg. R. R. Askew. Some to be deposited in MNCN and the Natural History Museum (London). 


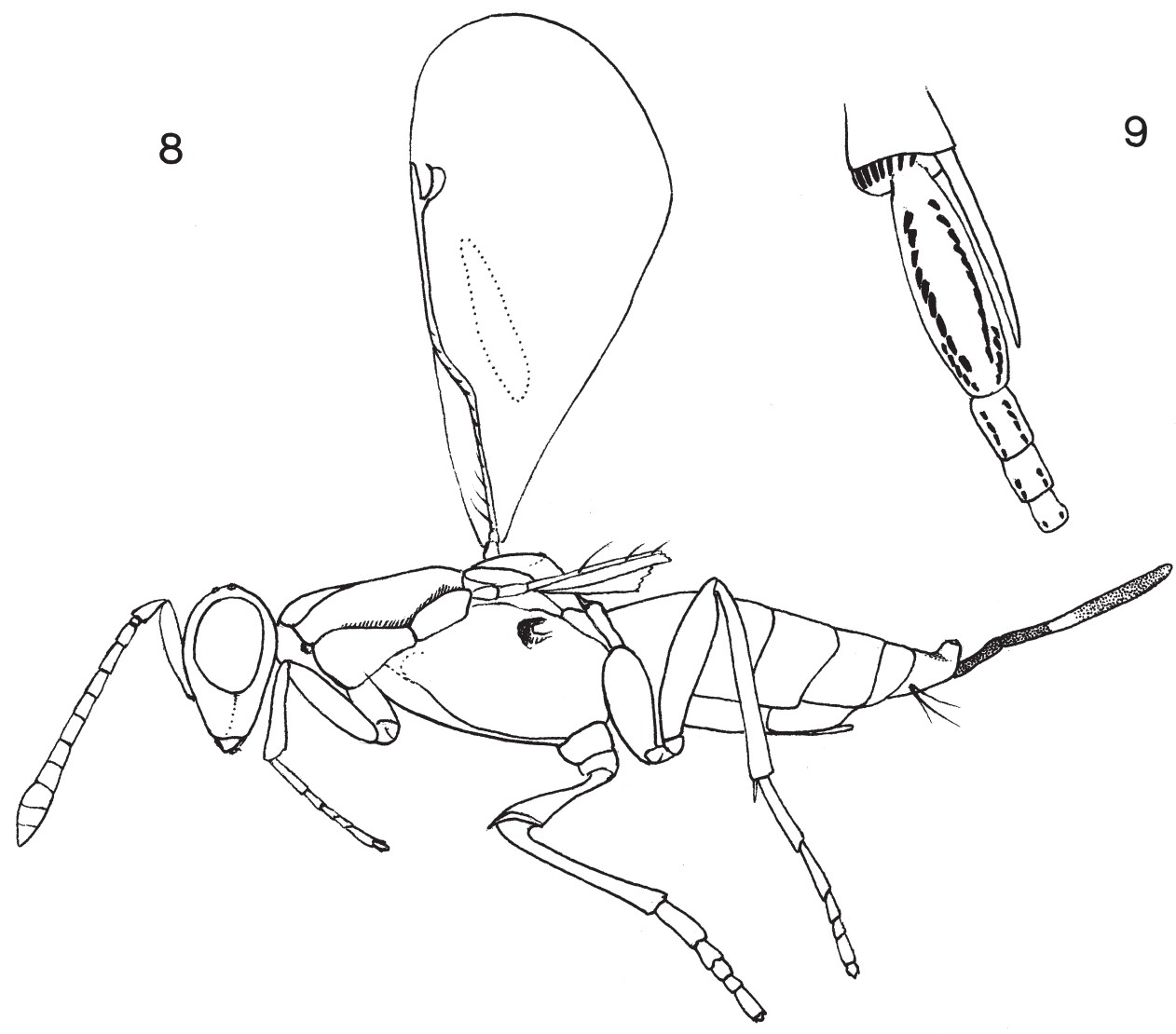

Figs. 8-9.- Eupelmus stenozonus sp. nov. 8) $ᄋ$ holotype body and right forewing (speculum indicated by broken line); 9) $ᄋ$ apex of mesotibia and four basal tarsal segments, in ventral view, showing arrangement of black pegs.

Figs. 8-9.- Eupelmus stenozonus sp. nov. 8) Cuerpo y ala anterior derecha del holotipo $ᄋ$ (speculum indicado por una líneqa de

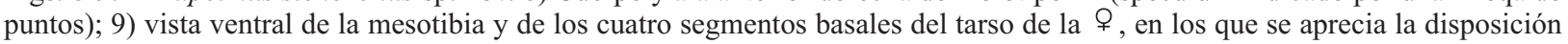
de las hileras de dentículos negros.

Additional material. La Gomera, Antoncojo, 26.iii.1999, 2 우 (damaged), RRA. Tenerife, Malpais Golmar, 16.iv.1986, 1 \% , M. Báez.

Female. Body dark green with extensive coppery reflections, especially from mesoscutum; prepectus and tegula metallic. Ovipositor sheath mainly dark, black at base and heavily infuscate apically, but with a narrow yellowish median annulation which occupies at most one-fifth (one-eighth in holotype) of the sheath and is shorter than the proximal black area (fig. 8). Antenna entirely dark with metallic reflections. Wings clear; venation testaceous. Front leg almost entirely black with metallic reflections; middle leg dark from coxa to about two-thirds length of femur, tibia testaceous with basal infuscate annulation, tarsal segments 1-3 tes- taceous, rest of tarsus infuscate; hind leg dark except apex of femur, extreme base and apical onefifth of tibia and tarsal segments 1-2(3). Length (including ovipositor) $2.7-3.7 \mathrm{~mm}$ (holotype 3.7 $\mathrm{mm})$.

Head in dorsal view 2.15 times as broad as long, slightly broader than mesoscutum; temples short, 0.1 times length of eye; POL about 2.2 times OOL, posterior ocellus separated from orbit by about 1.2 times its diameter. Head in front view 1.25 times as broad as high; eyes separated by 0.42 times head breadth; reticulate sculpture coarse between scrobe and eye, fine between mouth and eye. Antenna with pedicel plus flagellum 1.2 times as long as breadth of head; scape 4.2 times as long as broad with a ventral carina on distal two-thirds; pedicel 0.09 
times as long as flagellum, only 0.75 times as long as subquadrate anellus plus first funicle segment in holotype (in smaller specimens about equal to anellus plus F1); funicle broadening and segments shortening distally; F1 about 2.5 times as long as broad and slightly narrower than pedicel, F7 subquadrate and about twice as broad as pedicel; clava comprising 0.25 times length of flagellum and 2.4 times as long as broad.

Mesoscutum with posterior median depressed area entirely reticulate, more coarsely so than scutellum and axilla; scutellum slightly longer than broad; mesopleuron entirely reticulate, finely so on anterior third, extremely finely in a transverse median band, and more coarsely on posterior twofifths. Mesotibia with an apical row of 5 or 6 dark pegs in front of spur (fig. 9); ventral surfaces of mesotarsal segments 1-4 (fig. 9) with relatively long black pegs, on basitarsus arranged in two longitudinal rows on each side, the anterior rows each comprising 5-7 pegs and overlapping the longer posterior rows of 9-11 pegs each, on T2 in two rows of 4-5 pegs, on T3 in two rows of 2 pegs, and 2 apical pegs on T4. Metacoxa with dorsal surface pilose.

Forewing (fig. 8) with relatively long, sparse pilosity, the speculum relatively broad; ratio of lengths costal cell: marginal vein: stigmal vein: postmarginal vein as 17:14:3:3; stigma angled against stem of stigmal vein, rather large, separated from postmarginal vein by little more than its height and as long as stem of stigmal vein.

Gaster (fig. 8) excluding ovipositor sheath longer than mesosoma (29:26); ovipositor sheath almost 0.7 times length of rest of gaster and 1.16 times length of metatibia, the basal section (before constriction) long, occupying about 0.23 times the total length.

MALE. Head and thorax dark green, sides of thorax bluish green with mesepimeron mainly violet; legs dark, only 'knees' and extreme apices of tibiae of front and middle legs testaceous, two (three) basal segments of middle and hind tarsi whitish. Length 1.5-1.6 mm.

Antenna with scape only about 0.6 times height of eye, about 2.5 times as long as broad; pedicel plus flagellum 1.3 times as long as head breadth; flagellum filiform; first funicle segment subquadrate, as long as pedicel, shorter than F2 which is about 1.5 times as long as broad, F3-7 each about 1.8 times as long as broad, all funicle segments with short but dense pilosity standing out at an angle of about $40^{\circ}$. Gena with long seta only twice length of adjacent setae, rather thin and weakly curved.

Thorax as in other male Eupelmus. Forewing with speculum extending to about middle of marginal vein, partly open below; basal cell entirely pilose; marginal vein 3.2-3.4 times as long as postmarginal vein; stigma angled as in female, large, distinctly longer than stem of stigmal vein.

Gaster obovate, shorter than mesosoma, about twice as long as broad; reticulate sculpture on dorsal surface weakly raised.

Etymology. Stenos (Greek), narrow; zone (Greek), a girdle - referring to the narrow pale band on the ovipositor sheaths. Purists might not approve of deriving a trivial name from Greek, but I follow the precedent of "microzonus" and "urozonus".

COMmENTs. Eupelmus stenozonus is allied to the E. urozonus-group, having an entirely metallic thorax, black mesotarsal pegs, pale-banded ovipositor and short postmarginal vein. It is, perhaps, closest to E. annulatus but differs in its longer ovipositor with very narrow median pale band, the genal seta of the male is shorter and less curved, and the stigma in both sexes is larger.

E. testaceiventris (Motschulsky, 1863: 49)

Eupelmus valentinus Bolívar, 1933: 200, 201 syn. n.

Eupelmus valentinus was described by Bolívar from a female found at Bétera, Province of Valencia. This specimen could not be found in MNCN, but a female labelled 'Barcelona R. G. Mercet 23-8-927' agrees quite well with the description of $E$. valentinus except that the ovipositor sheaths are somewhat shorter, only about as long as the hind tibia and 0.4 times the length of the rest of the gaster (corresponding measurements given in the description are 1.25 and 0.5 times). This specimen is identified as E. testaceiventris, described from Ceylon but suggested to be widespread in the Mediterranean region and 'locally common in grassy vegetation in Spain - n. rec.' (Boucek, 1977).

In the Canary Islands E. testaceiventris is probably the most numerous species of Eupelmus and it has been found on Gran Canaria (1985, M. Báez), La Gomera (1999, M. Báez, M. Koponen, RRA), La Palma (1997 and 1998, M. Koponen), Tenerife (1973, P. J. Chandler; 1984-99, M. Báez and M. Koponen; 1999, RRA). It is a parasitoid of grass- 
dwelling Cecidomyiidae (Dipt.) and is found, together with E. moroderi, on the grass Hyparrhenia hirta.

\section{E. urozonus Dalman, 1820: 378 (aggregate)}

Reported by Ruschka (1921) from Olea near Barcelona, by Nieves-Aldrey (1982) as a parasitoid in a variety of galls of Cynipidae (Hym.) on Quercus in Salamanca, and by Pujade (1989) from galls of Cynipidae on Quercus and Rosa, from Myopites olivieri Kieffer (Dipt., Tephritidae) on Inula and Mikiola fagi Hartig (Dipt., Cecidomyiidae) on Fagus in Catalunya. Gijswijt (1993) records E. urozonus from galls of a cecidomyiid (Etsuhoa thuriferae) on Juniperus thurife$r a$ in Soria, and Askew \& Blasco-Zumeta (1997, 1998) report its rearing from Blascoa ephedrae Askew (Hym., Pteromalidae) and Eurytoma gallephedrae Askew (Hym., Eurytomidae) on Ephedra nebrodensis Tineo in Los Monegros. Unpublished rearing records are from Diplolepis rosae (L.) (Hym., Cynipidae) (Jaca, 1992, RRA), D. mayri (Schlechtendal) (Logroño, Ezcaray, 1994, RRA), Myopites galls on Inula (Gerona, Tossa de Mar, 1961, RRA; Majorca, 1982, M. Boness) and fruits of Juniperus phoenicea L. (Canary Islands, La Gomera, 1999, RRA).

The broad host range, together with some very small morphological differences, suggest that $E$. urozonus as currently understood comprises an aggregate of forms which are poorly-differentiated morphologically but distinct biologically.

In MNCN there are specimens of E. urozonus agg. from Almería (Mercet collection), Madrid (RGM), Santander (RGM) and Segovia (CBP). Additional localities include San Sebastián (1964, RRA), Jaén (1974, RRA) and Andorra (1992, JPV) and, in the Canary Islands, La Palma (1997 and 1998, M. Koponen) and Tenerife (1989, M. Koponen and 1996, M. Báez).

\section{Eupelmus (Macroneura)}

\section{E. (M.) aseculatus Kalina, 1981: 96-99 comb. n.}

New record for peninsular Spain: Madrid, Vaciamadrid, 1918, CBP (MNCN), El Escorial, 1910, RGM and 1919, CBP (MNCN); Avila, Chamartín, 1918, RGM (MNCN); Jaén, 1974, RRA.

Specimens reared from galls of Callirhytis glandium (Giraud) and C. rufescens (Mayr) (agamic generations) (Hym., Cynipidae) on Quercus suber from Toledo (1989, JNA) have also been examined.

\section{E. (M.) falcatus (Nikol'skaya, 1952: 493) comb. n.}

New record for peninsular Spain: Two females from Madrid, Vaciamadrid, 1918, CBP and Montarco, 1907, Cabrera are in MNCN.

A third female in $\mathrm{MNCN}$ is probably E. falcatus but is unusual in having an infuscate scape; it is from Madrid, El Pardo, no date, RGM.

\section{E. (M.) maculatus (Ferrière, 1954: 9) comb. n.}

New record for peninsular Spain: $1 \stackrel{9}{\text {, }}$ Barcelona, 1974, Z. Boucek in RRA collection.

\section{E. (M.) muellneri Ruschka, 1921: 305 comb. rev.}

Not previously recorded from mainland Spain, but listed from the Canary Islands (La Gomera, Tenerife) by Gijswijt (1990).

Reared from Myopites (Dipt. Tephritidae) galls on Inula, Gerona, Tossa de Mar, 1961, RRA and Majorca, 1982, M. Boness and Isocolus lichtensteini (Mayr) (= tavaresi Nieves-Aldrey) (Hym., Cynipidae) galls on Centaurea nicaeensis All., Formentera, 1987, M. Boness. Also reared from Stephaniella atriplicis (Kieffer) (Dipt., Cecidomyiidae) on Atriplex halimus L. and from stems of Eryngium maritimum L., Portugal, Algarve, Albufeira, 1995, M. Boness. Additional material from Valencia, no date, RGM (MNCN); Alicante, Torrevieja, 1974, Z. Boucek; Granada, Calahonda, 1988, RRA; Zaragoza, Pina de Ebro, 1992, JBZ.

\section{E. (M.) seculatus (Ferrière, 1954: 5-7) comb. n.}

Pujade (1989) reared this species from cecidomyiid (?) galls on Ononis in Catalunya, and described the male.

Additional records: Madrid, Vaciamadrid, 1923, CBP (MNCN); El Pardo, no date, RGM (MNCN); Loeches, 1924, RGM (MNCN); Torrelodones, 1906, Cabrera; Castellón, Benicasim, 1974, Z. Boucek; Zaragoza, Pina de Ebro, ex galls Rhopalomyia (Dipt., Cecidomyiidae) on Artemisia herba-alba Asso, 1996, JBZ. A female with scape darkened and weakly metallic, from Vaciamadrid 
(1923, RGM (MNCN)), is questionably referable to E. seculatus.

\section{E. (M.) vesicularis (Retzius, 1783: 70, no. 291)}

Cited from Majorca (Askew, 1975) and as a parasitoid in several cynipid galls on Quercus in Salamanca (Nieves-Aldrey, 1982). Pujade (1989) reported its hosts in Catalunya as Diastrophus rubi (Bouché) (Hym., Cynipidae) on Rubus, Myopites olivieri Kieffer (Dipt., Tephritidae) on Dittrichia and Mikiola fagi Hartig (Dipt., Cecidomyiidae) on Fagus. Specimens have also been reared from galls of Rhopalomyia (Dipt., Cecidomyiidae) on Artemisia at Zaragoza, Pina de Ebro, 1996, JBZ, and from the following Cynipidae by JNA:

Liposthenus kerneri (Wachtl) on Nepeta latifolia D.C., Madrid, El Ventorillo, 1989

Phanacis caulicola (Hedicke) on Picris echioides L., Guadalajara, Valdenoches, 1990

Phanacis centaureae on Centaurea nigra L., Guadalajara, El Cardoso de la Sierra, 1986, and on C. scabiosa, Guadalajara, Tamajón, 1987

Timaspis phoenixopodos (Mayr) on Lactuca viminea (L.), Madrid, Puerto de la Morcuera, 1985

Non-reared material in $\mathrm{MNCN}$ was obtained from Madrid, Cercedilla, no date, CBP, El Pardo, no date, RGM and El Escorial, 1892 \& 1924, CBP; Segovia, San Rafael, no date, CBP; San Sebastián, 1918, RGM; Bilbao, no date, RGM; La Coruña, no date, RGM. Additional material has been examined from Gerona, Tossa de Mar, 1961, RRA; San Sebastián, Orio, 1964, RRA; and from Jaca (1973), Val d'Aran (1994) and Gavarnie (1977), all RRA in the Pyrenees.

\section{E. (M.) sp. indet. A}

1 ㅇ, Madrid, El Pardo, 1928, RGM (MNCN); 1 , Madrid, Zarzalejo, no date, RGM (MNCN).

These two specimens are probably conspecific. They both have infuscate scapes and pale mesobasitarsal pegs, and appear to belong to the E. schmiedeknechti Ruschka group (Kalina, 1981). Further material is required to ascertain their identity.

\section{E.(M.) sp. indet. B}

$4 ㅇ ㅗ$, ex gall Aylax papaveris (Perris) on Papaver sp., Malaga, Embalse del Chorro, 1987, JNA.
This material represents a species near $E$. (M.) aseculatus.

\section{Key to Spanish species of Eupelmus Dalman (females only)}

Keys to most Palaearctic species of the subgenera Eupelmus and Macroneura will be found respectively in Kalina (1988) and Kalina (1981).

1. Macropterous, or if brachypterous (E. atropurpureus), then pronotum without a setose transverse crest; gaster seldom pale only at base but sometimes extensively yellowish; scape most often dark and metallic, sometimes bicoloured, rarely yellow ....................... 2 Brachypterous; pronotum with a transverse crest bearing a row of stout setae; gaster nearly always with base of first tergite contrastingly pale; scape yellow (except in unidentified species) (Macroneura) ...... 23

2(1) Brachypterous, forewing truncate, triangular, clear, not upturned, with venation complete, the stigmal vein parallel with and close to apical margin; body black with purple reflections; ovipositor all black, not quite half as long as hind tibia .. E. atropurpureus Dalman Macropterous

Mesoscutum posteriorly reticulate, not more shiny than scutellum and axillae (in E. clavicornis mesoscutum almost smooth but scutellum and axillae also very weakly sculptured and shiny); forewing clear or with general infumation, rarely with a discal cloud ........ 4 Mesoscutum posteriorly smooth and shiny, contrasting with dull, strongly sculptured scutellum and axillae; forewing with an infumate mark below parastigma and another below stigmal vein, the two marks often connected by weaker infumation .................. 20 Mesotibia at apex and ventral surface of mesobasitarsus with at least some black pegs (e.g. fig. 9); ovipositor very dark basally, pale-banded medially and darkened apically, rarely (E. stenozonus) longer than hind tibia

Mesotibia and mesobasitarsus without black pegs, pegs either absent, pale or brown; ovipositor sometimes uniformly dark, sometimes longer than hind tibia ........ 11

5(4) Forewing entirely pilose without a speculum; mesopleuron dull, relatively strongly reticulate, more finely so centrally but nowhere almost smooth

E. aloysii Russo Forewing with speculum represented by a bare, oblique linear area (linea calva) below parastigma and basal part of marginal vein; mesopleuron rather shiny, its sculpture fine and weak, parts of disc sometimes almost smooth ......................................................... 6

6(5) Ovipositor sheath distinctly longer than hind tibia and almost 0.7 times as long as rest of gaster (fig. 8) ...... E. stenozonus Askew Ovipositor sheath at most about as long as hind tibia and 0.5 times as long as rest of gaster …………..... 7

7(6) Ovipositor sheath about as long as hind tibia ............ 8 Ovipositor sheath at most 0.8 times length of hind tibia 
8(7) Scape mostly yellowish, testaceous or reddish .................................................. E. cerris Förster Scape dark with metallic reflections

E. annulatus Nees

9(7) Marginal vein relatively short, a little more than twice as long as postmarginal vein which is about 1.2 times as long as stigmal vein; mesobasitarsus with fewer than ten dark pegs ventrally .. E. microzonus Förster Marginal vein about 4 times length of postmarginal vein which is sometimes not longer than stigmal vein; mesobasitarsus with more than twenty dark pegs ventrally .. 10

10(9) Legs except coxae yellow, or at most with some infuscation on front femur; postmarginal vein slightly longer than stigmal vein ................... E. fulvipes Förster Legs with femora and tibiae partly infuscate; postmarginal vein not longer (usually slightly shorter) than stigmal vein .............................. E. urozonus Dalman

11(4) Thorax including prepectus and tegulae metallic, gaster metallic ..................................................... 12 Thorax with prepectus and tegulae yellow, gaster usually partly yellowish ......................................... 15

12(11) Legs except coxae yellow; ovipositor sheaths hardly one-quarter length of gaster and not quite half as long as hind tibia .............................................. sp. indet. Legs with femora and tibiae partly infuscate; ovipositor sheaths longer .................................................. 13

13(12) Ovipositor sheaths broadly pale with only bases and apices darkened (half length of gaster, 0.7 times length of hind tibia); thoracic dorsum exceedingly weakly sculptured, partly smooth, shiny; forewing clear; antenna (fig. 7) strongly clavate, clava broader than scape which is about 4 times as long as broad, anellus paler than rest of flagellum; hind coxa with dorsal surface bare in basal half .............. E. clavicornis Askew Ovipositor sheaths uniformly dark, sometimes longer than in alternate; thoracic dorsum densely reticulate; forewing usually weakly infumate; antenna weakly clavate, clava narrower than scape which is less than 3 times as long as broad, anellus and rest of flagellum concolorous; hind coxa dorsally pilose .................. 14

14(13) Ovipositor sheaths $0.55-0.75$ times length of gaster, 1.6 - 2.0 times length of hind tibia; mesotibia broadly infuscate medially .......... E. fuscipennis Förster Ovipositor sheaths 0.4 times length of gaster, 0.85 times length of hind tibia; mesotibia with a subbasal infuscate band occupying about one-third the length

[E. hartigi Förster]

15(11) Ovipositor sheaths at least 5.5 times as long as hind tibia, entirely dark ................... E. moroderi Bolívar Ovipositor sheaths at most 2 times as long as hind tibia, with a median pale band more or less indicated ...... 16

16(15) Forewing with linear speculum; ovipositor sheaths 2 times as long as hind tibia ............. E. linearis Förster Forewing without speculum; ovipositor sheaths at most only slightly longer than hind tibia .............. 17

17(16) Antenna dark with only anellus pale; marginal vein length about 2.5 times postmarginal vein and 3.7 times stigmal vein .. E. testaceiventris (Motschulsky) Antenna with flagellum pale, only basal funicle segments somewhat darkened, basal half of scape yellow; marginal vein length about 1.5 times postmarginal and 2.0 times stigmal vein .. 18
18(17) Thoracic dorsum metallic with only prepectus, tegulae and sometimes lateral and posterior edges of mesoscutum, yellow; ovipositor sheaths at least 0.5 times as long as rest of gaster ............. E. pallicornis Gijswijt Thorax dorsally bicoloured (fig. 5), mesoscutum yellow with a broad, median, metallic green stripe and an oval, green spot on each side; ovipositor sheaths at most 0.3 times as long as rest of gaster ................ 19

19(18) Ovipositor sheaths about 0.3 times as long as rest of gaster (fig. 5) and 0.6 times as long as hind tibia. Associated with Juniperus oxycedrus

E. juniperinus juniperinus Bolívar Ovipositor sheaths very short, only 0.13 times as long as rest of gaster (fig. 6) and 0.3 times as long as hind tibia. Associated with Juniperus thurifera

E. juniperinus thuriferae Askew

20(2) Antenna with funicle segments 2-5 white; ovipositor sheaths entirely dark, slightly longer than hind tibia, mesobasitarsus without black pegs; forewing narrow with marginal vein length 4.0 times postmarginal vein and more than 7.0 times stigmal vein; thorax metallic; scape reaching above vertex; metatibia darkened over apical one-third, mesotibia with a broad basal dark band; hind coxa bare dorsally in basal half

E. hungaricus Erdös Antenna with funicle unicolorous dark; ovipositor sheaths with pale median band, shorter than hind tibia; mesobasitarsus sometimes with black pegs; forewing not narrow with marginal vein length only slightly more than 2.0 times postmarginal vein and at most 3.3 times stigmal vein; prepectus, tegula and sides of pronotum non-metallic reddish yellow; scape sometimes not reaching above vertex; tibiae reddish with weak basal infuscations; hind coxa dorsally pilose ........ 21

21(20) Forewing speculum absent, stigma with exceptionally long uncus 0.7 times length of stigmal vein, marginal vein more than 3.0 times as long as stigmal vein; mesobasitarsus ventrally without dark pegs; antenna with scape reaching above vertex and all funicle segments longer than wide ............ E. rostratus Ruschka Forewing speculum present, stigma normal without lengthened uncus, marginal vein 2.0 times as long as stigmal vein; mesobasitarsus ventrally with black pegs; scape not reaching above vertex and last funicle segment slightly transverse, F6 subquadrate ........ 22

22(21) Ovipositor sheaths (fig. 1) relatively short, 0.6-0.7 times length of hind tibia and 0.31-0.36 times as long as rest of gaster; gaster (fig. 1) not more than 1.1 times as long as mesosoma; head in dorsal view 1.75-1.9 times as broad as long; larger species, length 2.2-2.8 $\mathrm{mm}$........................................... E. matranus Erdös Ovipositor sheaths (fig. 2) 0.9 times to almost as long as hind tibia and 0.42-0.50 times as long as rest of gaster; gaster at least 1.2 times as long as mesosoma; head in dorsal view about 1.6 times as broad as long; smaller, more slender species, length $1.7-2.0 \mathrm{~mm}$.......

E. splendens Giraud [Males of E. matranus and E. splendens differ as described in the text]

23(1) Reduced forewing divided into a basal, apically truncate section and an apical part which is bent upwards (the apical part may be broken off); hindwing present; mesopleuron finely striate ......................................... 24 
- $\quad$ Forewing reduced to a small, undivided hyaline scale which is apically rounded and adpressed to the thorax; hindwing absent; mesopleuron more strongly longitudinally striate 27

24(23) Apical section of forewing distally rounded, not pointed; mesobasitarsus with ventral dark pegs

E vesicularis (Retzius)

- $\quad$ Apical section of forewing distally pointed; mesobasitarsus sometimes without ventral dark pegs ......... 25

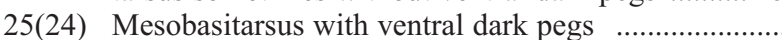
E. seculatus (Ferrière) Mesobasitarsus without dark pegs ..................... 26

26(25) Apical infuscate section of forewing longer than half of gaster (excluding ovipositor sheaths) and with stigmal vein visible at about half of its length; ovipositor sheaths about $0.20-0.25$ times as long as rest of gaster and $0.35-0.48$ times length of hind tibia

E. falcatus (Nikol'skaya)

- Apical infuscate section of forewing shorter than half gastral length and with stigmal vein undeveloped; ovipositor sheaths about 0.4 times as long as rest of gaster and 0.6 times length of hind tibia

E. aseculatus (Kalina)

27(23) Scape dark, sometimes metallic ............. sp(p). indet.

- $\quad$ Scape yellow or testaceous ................................ 28

28(27) Ovipositor sheaths one-third length of rest of gaster; tegulae dark; mesobasitarsus on each side of ventral surface with 1 or 2 basal pegs and 1 apical peg

E. muellneri Ruschka

- Ovipositor sheaths one-sixth length of rest of gaster; tegulae white; mesobasitarsus without dark pegs ...... E. maculatus (Ferrière)

\section{Acknowledgements}

We acknowledge with gratitude the following who have generously supplied one of us (RRA) with specimens, information or both: Javier Blasco-Zumeta, Martin Boness, Zdenek Boucek, Theo Gijswijt and Juli Pujade. Our thanks also to Gary Gibson whose very helpful comments initiated several improvements to this paper. This work was granted to JLNA for the research projects DGES PB97-1241, Spanish Ministry of Education and Culture and the project "Inventory and study of the invertebrate faune of the Caldera de Taburiente National Park", Organismo Autónomo, Parques Nacionales.

\section{References}

Askew, R. R., 1975. Some Chalcidoidea from Majorca, with descriptions of two new species. Eos, 46(1973): 13-27.

Askew, R. R. \& Blasco-Zumeta, J., 1997. Parasitic Hymenoptera inhabiting seeds of Ephedra nebrodensis in Spain, with descriptions of a phytophagous pteromalid and four other new species of Chalcidoidea. Journal of Natural History, 31: 965-982.

Askew, R. R. \& Blasco-ZumetA, J., 1998. Insects associated with galls of a new species of Eurytomidae (Hymenoptera: Chalcidoidea) on Ephedra nebroden- sis in Spain. Journal of Natural History, 32: 805821.

Bolívar y Pieltain, C., 1933. Estudio de algunos eupélmidos nuevos de España (Hym. Chalc.). Eos, 9: 195209.

BouceK, Z., 1968. Contributions to the Czechoslovak fauna of Chalcidoidea (Hym.). Acta Entomologica Musei Nationalis Pragae, 12: 231-260.

BouceK, Z., 1977. A faunistic review of the Yugoslavian Chalcidoidea (Parasitic Hymenoptera). Acta entomologica Jugoslavica, 13 suppl.: 1-145.

BouceK, Z., 1988. Australasian Chalcidoidea (Hymenoptera) A Biosystematic Revision of Genera of Fourteen Families, with a Reclassification of Species. C.A.B. International. Wallingford. $832 \mathrm{pp}$.

Ceballos, G., 1956. Catálogo general de los Himenópteros de España. Instituto Español de Entomología. Madrid. 420 pp.

Dalman, J. W., 1820. Försök till Uppställning af Insekfamiljen Pteromalini, i synnerhet med åfseende på de i Sverige funne arter. Kungliga Svenska Vetenskapsakademiens Handlingar, 41: 340-385 (partim).

ERDÖS, J., 1947. Eupelmus matranus spec. nov. (Hymen., Chalc., Eupelmidae). Folia entomologica Hungarica, 2(s.n.): 68-70.

ERDÖs, J., 1959. Species nova Eupelmidarum in territorio reservato Bátorliget detecta. Folia entomologica Hungarica, 12: 327-330.

FERriÈre, C., 1954. Eupelmides brachyptères (Hym. Chalcidoidea). Mitteilungen der Schweizerischen Entomologischen Gesellschaft, 27: 1-21.

FÖRSTER, A., 1841. Beiträge zur Monographie der Pteromalinen, Nees. I. Aachen. 47 pp.

FörSTER, A., 1860. Eine Centurie neuer Hymenopteren. Verhandlungen der naturhistorischen Vereins der Preussischen Rheinlande, 17: 93-153.

GiBson, G. A. P., 1995. Parasitic wasps of the subfamily Eupelminae: classification and revision of world genera (Hymenoptera: Chalcidoidea: Eupelmidae). Memoirs on Entomology, International, 5: 1-421.

Gisswist, M. J., 1990. Chalcidoidea of Canary Islands (Hymenoptera). Vieraea, 18: 103-112.

Gisswist, M. J., 1993. Species of Eupelmus (Hymenoptera: Chalcidoidea) on Spanish juniper. Entomologische Berichten, 53: 10-12.

GIRAUD, J., 1871. Miscellanées hyménopterologiques. III. Description d'Hyménoptères nouveaux avec l'indication des moeurs de la plupart d'entre eux et remarques sur quelques espèces déjà connues. Annales de la Société Entomologique de France, 1(5 ser.): 389-419.

Girault, A. A., 1915. Australian Hymenoptera Chalcidoidea - VII. The family Encyrtidae with descriptions of new genera and species. Memoirs of the Queensland Museum, 4: 1-184. 
Graham, M. W, R, DE V., 1969. Some Eupelmidae (Hymenoptera: Chalcidoidea) new to Britain, with notes on new synonymy in this family. Proceedings of the Royal Entomological Society of London (B), 38: 89-94.

Kalina, V., 1981. The Palearctic species of the genus Macroneura Walker, 1837 (Hymenoptera, Chalcidoidea, Eupelmidae), with descriptions of new species. Sbornik Vedeckého Lesnického ústavu Vysoké skoly zemedelské v Praze, 24: 83-111.

Kalina, V., 1988. Descriptions of new Palearctic species of the genus Eupelmus Dalman with a key to species (Hymenoptera, Chalcidoidea, Eupelmidae). Silvaecultura Tropica et Subtropica, 12: 3-33.

Motschulsky, V. DE, 1863. Essai d'un catalogue des insectes de l'Ile Ceylan. Bulletin de la Société Impériale des Naturalistes de Moscou, 36: 1-153.

NeEs AB EsENBECK, C. G., 1834. Hymenopterorum Ichneumonibus affinium monographiae, genera Europaea et species illustrantes, 2. Stuttgart \& Tubingen. $448 \mathrm{pp}$.

Nieves-Aldrey, J. L., 1982. Eupélmidos (Hym. Eupelmidae) que parasitan a los pobladores de las agallas de cinípidos producidas en especies del género Quercus en la provincia de Salamanca. Boletín de la Asociación española de Entomología, 5(1981): 143-150

NiKOL'SKAYA, M. N., 1952. Chalcidii Fauni SSSR (Chalcidoidea). Moscow \& Leningrad. 575 pp.
Pujade i Villar, J., 1989. Primeros datos sobre los eupélmidos asociados a agallas en Cataluña (Hym., Chalcidoidea, Eupelmidae) con la descripción del macho de Macroneura seculata (Ferrière, 1954). Orsis, 4: 151-160.

Retzius, A. J., 1783. Caroli de Geer genera et species insectorum. Lipsiae. 226 pp.

RuschKA, F., 1921. Chalcididenstudien. I. Teil. Verhandlungen der Zoologisch-Botanischen Gesellschaft in Wien, 70: 234-315.

Russo, G., 1938. VI. Contributo alla conoscenza dei Coleotteri Scolitidi Fleotribo: Phloeotribus scarabaeoides (Bern.) Fauv. Parte seconda Biografia, simbionti, danni e lotta. Bollettino del R. Laboratorio di Entomologia Agraria di Portici, 2: 3-420.
Recibido, el 17-XI-1999

Aceptado, el 27-IX-2000 Publicado, el 27-XII-2000 